\title{
Actual Achievements on Germ Cells and Gametes Derived from Pluripotent Stem Cells
}

\author{
Irina Kerkis ${ }^{1}$, Camilla M. Mendes ${ }^{2}$, Simone A. S. da Fonseca ${ }^{1}$, \\ Nelson F. Lizier ${ }^{1}$, Rui C. Serafim ${ }^{1}$ and Alexandre Kerkis ${ }^{3}$ \\ ${ }^{1}$ Laboratory of Genetics, Butantan Institute, \\ ${ }^{2}$ School of Veterinary Medicine, University of São Paulo, \\ ${ }^{3}$ CELLTROVET (Genética Aplicada), Ltda.
}

Brazil

\section{Introduction}

Germ cells (GC) appeared very early in embryonic development and are maintained over life period in order to give rise to the gametes of organisms that reproduce sexually (Fig. 1). These cells provide continuous tie between the generations (Donovan \& de Miguel 2003, McLaren 2003).
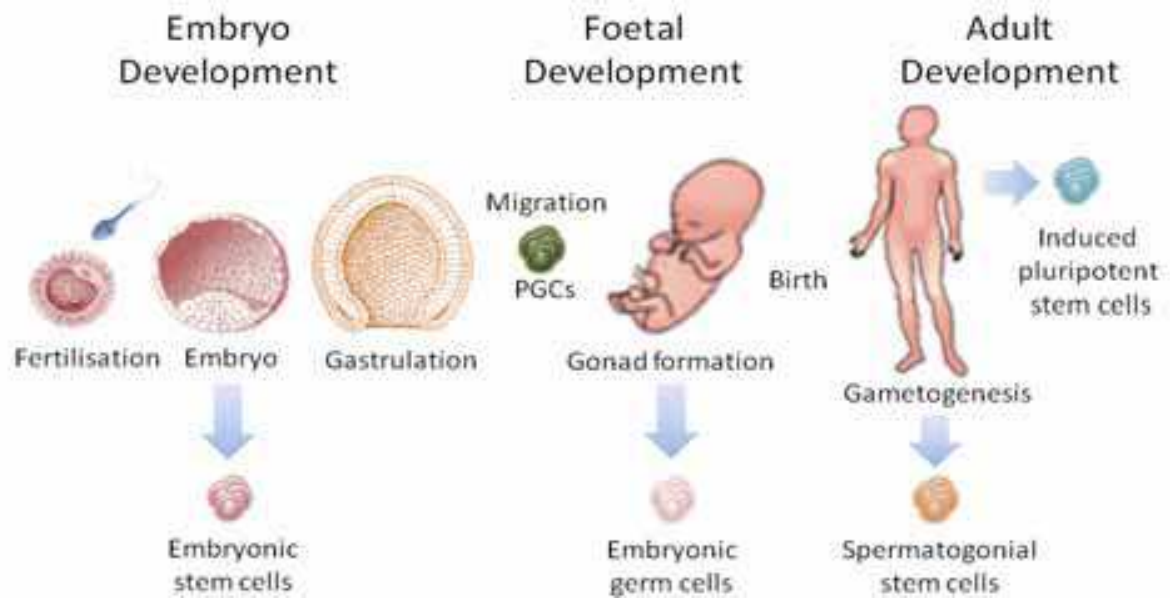

Fig. 1. Germ cells lifespan.

In mammals, the specification of GC begins during cleavage; GC first appears near the gut and further migrates to the developing gonads. The lineage of GC is called germ line. They are unique cells, which undergo cell division of two types, mitosis and meiosis, in contrast to somatic cells of mammal's body, which only divide by mitosis. Accordingly to Fig. 2 following further differentiation GC can be transformed into mature gamete, either eggs or sperm (Adams \& McLaren, 2002). There is growing evidence for effects of environmental 
chemicals on the various early stages of GC and gametes development (Baillie et al., 2003). Therefore, elucidating of the mechanisms controlling GC and gametes development is crucial for understanding an etiology of various aspects of infertility. Due to the complexity of natural process of mature gametes formation from GC and in order to provide in vitro model of GC development and fate, embryonic stem (ES) cells were recently used (Nagy et al., 2008).

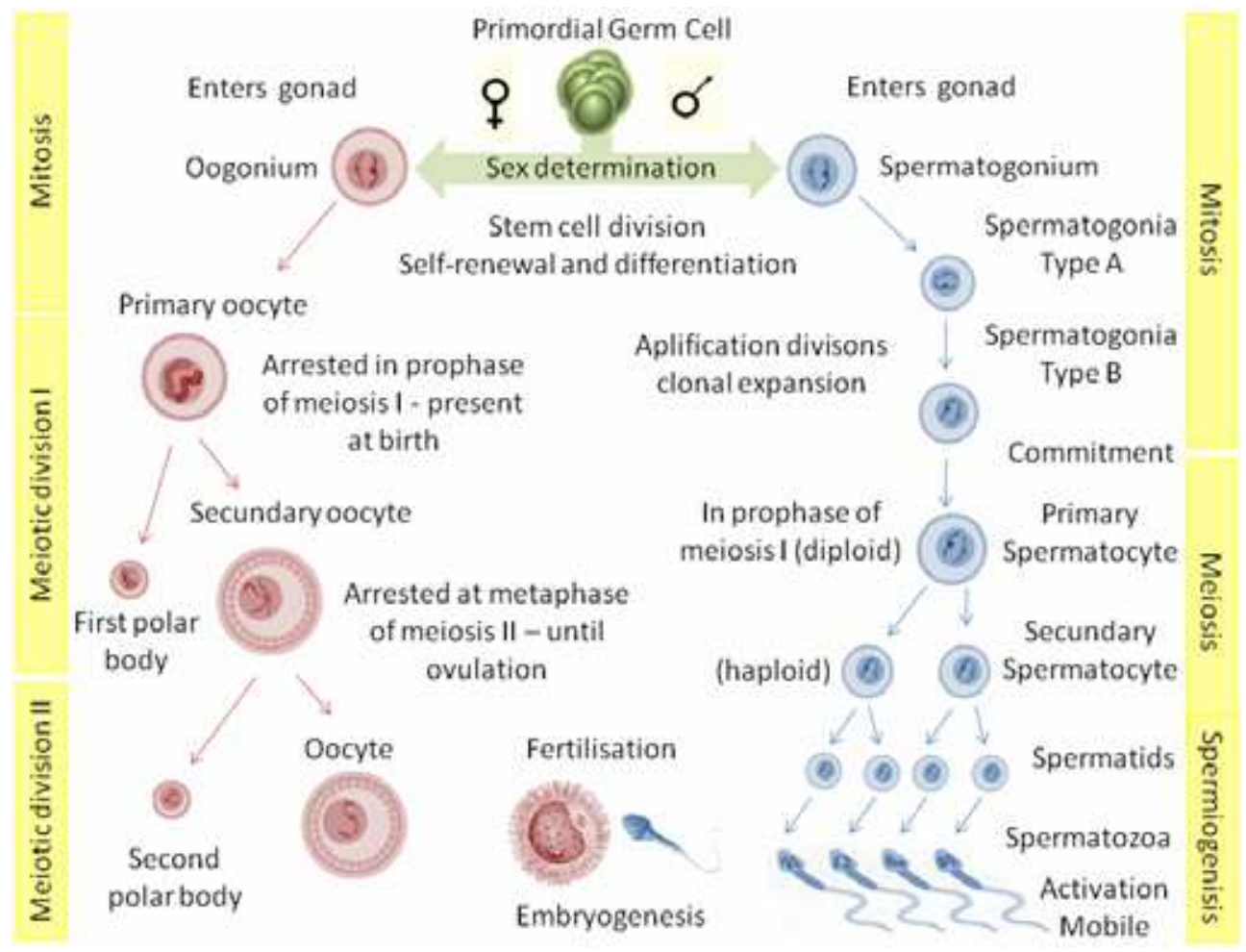

Fig. 2. Gametogenesis.

In vitro derivation of GC and male- and female-like gametes from pluripotent mouse embryonic stem (mES) cells was achieved using adherent cells (monolayer cell culture) and three-dimensional structures called embryoid bodies (EB), which present in vitro model of pre-implantation embryos, however chaotically organized. A variety of culture media have been also tested. These protocols are contradictory in respect of timing needs for GC generation from mES cells, which varies from 11 to 43 days in different studies; summarized in Fig. 3 and 4. The other difficulty is a lack of appropriate molecular markers for the characterization of the undifferentiated GC. The markers of early primordial GC (PGC) such as Stella, C-kit and Fragillis have key roles in GC competency and development, while Dazl and Vasa express in premeiotic GC. However, all these genes are also expressed in ES cells (Aflatoonian and Moore, 2006; Ko \& Schöler, 2006; Nagano, 2007; Daley, 2007; Hua and Sidhu, 2008; Marques-Mari, 2009). 


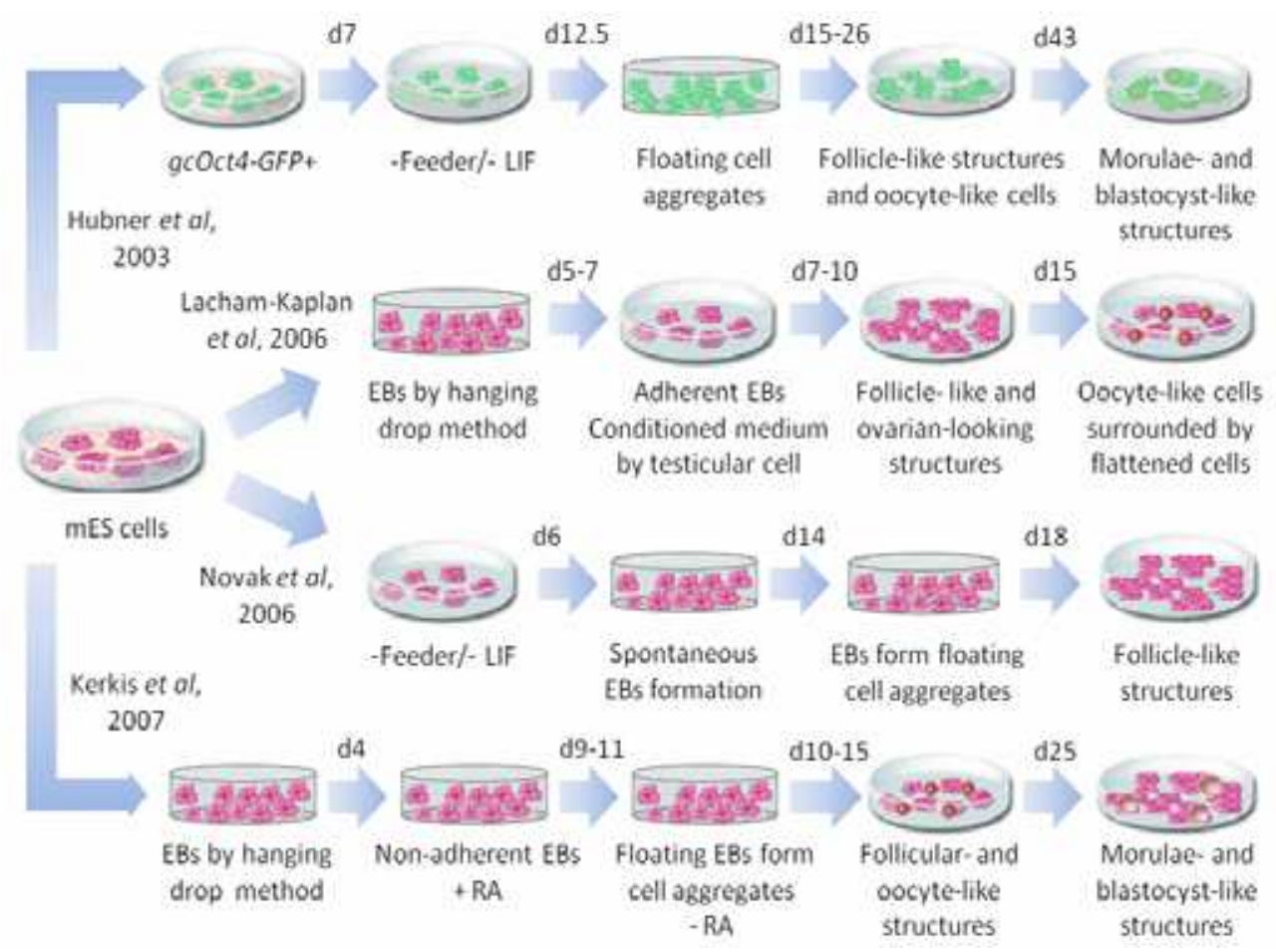

Fig. 3. Presumptive female GC and gametes derived from ES cells.

Genetically modified ES cells using fluorescent proteins linked to specific gene promoters (genes implicated in pluripotency or GC line fate) have been used in order to pre-select committed PGC and to provide more efficient harvesting of mature GC (Hubner et al., 2003, Toyooka et al., 2003, Nayernia et al., 2006). Although genetic modification facilitates the process of GC isolation, in the future such genetically modified GC (GM-GC) would have limited practical utilization especially in clinical procedures. Therefore, other research groups have a propensity to establish efficient protocols of GC isolation from native ES cells (Geijsen et al., 2004; Lacham-Kaplan et al., 2006; Kerkis et al., 2007).

The data about morphological and ultrastructural features, GC and gametes stage-specific proteins expression and GC epigenetic modification pattern are incomplete and need to be deepened (Aflatoonian and Moore, 2006; Nagy et al., 2008; Hua and Sidhu, 2008; MarquesMari, 2009). Meiosis is pre-requisite for functionally normal gametes formation and its investigation is indeed insufficient (Novak et al., 2006; Kerkis et al., 2007). A single attempt was made to demonstrate the functional state of gametes obtained from mES cells. It showed that the integration of artificial gametes with genetic material of normal eggs theoretically can occur. However, live offspring, which were obtained in this study died soon after birth (Nayernia et al., 2006). Therefore, experiments of other research groups are needed in order to confirm this study. 


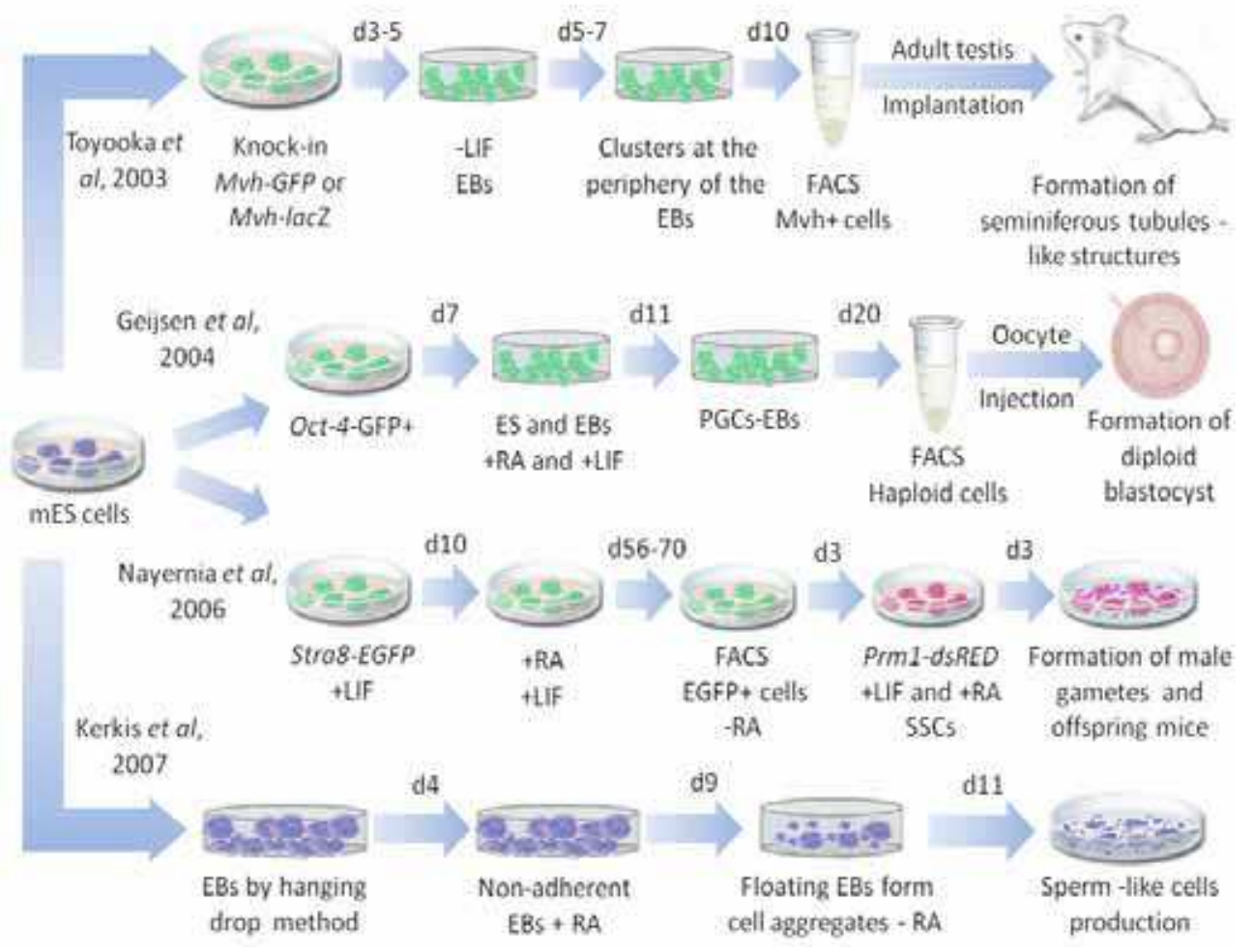

Fig. 4. Presumptive male GC and gametes derived from ES cells.

This chapter is focused on critical discussion of the actual achievements on GC and gameteslike in vitro generation from pluripotent stem cells, such as, $\mathrm{mES}$ and human embryonic stem (hES) cells (Evans \& Kaufman 1981, Martin 1981, Thomson et al., 1998) and reprogrammed cells: induced pluripotent (iPS) cells (Takahashi \& Yamanaka 2006) and somatic cell hybrids (Mittmann et al., 2002; Lavagnolli et al., 2009).

\section{Embryonic stem cells}

The ES cells are derived from early embryo, more precisely from morulae or inner cell mass (ICM) of blastocysts. ES cells can be maintained and expanded indefinitely in culture, while retaining their ability to produce all cell types in the body. This ability, which is also denominated as a pluripotency, is an extremely important property of ES cells. These cells are growing in monolayer and express in undifferentiated state a set of pluripotent markers among which Oct3/4, Nanog and Sox2. The mES cells additionally require leukemia inhibitory factor (LIF) in order to maintain undifferentiated state. Differentiation potential of ES cells provides a unique tool to generate various cell types in vitro and represent unlimited experimental model to study cell lineage commitment, which can be modified by cell culture conditions, external factors and spatial orientation (Evans \& Kaufman 1981, Martin 1981, Thomson et al., 1998). 


\subsection{Differentiation assay}

Generally two basic methods are used for GC differentiation from ES cells. One of them consists in adherent ES cell culture and differentiation after removing factors that promote pluripotency as feeders and basic fibroblast growth factor (bFGF) or LIF (Hübner et al., 2003; Nayernia et al., 2006b; Novak et al., 2006; Chen et al., 2007), whereas the second one implicates with the formation of three-dimensional structures known as EB, which further allowed to adhere on plastic dishes and differentiate (Clark et al., 2004; Geijsen et al., 2004; Lacham-Kaplan et al., 2006; Kerkis et al., 2007). Wei et al., (2008) compared GC, which were derived via attachment culture technique and via EB method. They demonstrated that the process of PGC derivation was more faithfully recapitulated using the EB method. Next, the ES cells can undergo spontaneous or induced differentiation. Spontaneous differentiation occurs in ES cells culture medium without MEF or growth factors besides those present in heat-inactivated serum, while induced differentiation required addition of growth factor or other chemicals: e.g. bone morphogenic protein 4 (BMP-4) or retinoic acid (RA) are usually used to induce GC differentiation in vitro. RA is a potent growth activator of mouse PGC (Koshimizu et al., 1995). During gametogenesis, the exposure to RA controls the progress of GC through meiosis and the differentiation of GC into male or female phenotypes (McLaren, 2003; Bowles et al., 2006; Bowles and Koopman, 2007; Doyle et al., 2008).

\subsubsection{Derivation of female GC and artificial gametes}

For the first time female GC were obtained in vitro by Hübner and colleagues (2003), which used female mES cells carrying gcOct4-GFP gene reporter. Prior differentiation experiments these cells were tested in transgenic animals and expression of gcOct-4-GFP gene in GC but in blastocyst or epiblast-stage embryo were not demonstrated. These cells were maintained adherent in ES cells culture medium without any feeder cells or growth factors besides those present in heat-inactivated serum. Large cell colonies, which formed by day 12 (d12) were composed by cells expressing GFP+ or GFP+/ Vasa+ or Vasa+ suggesting a presence of premigratory, migratory and early postmigratory GC. Vasa+ cells, which were physically separated from each other, detached simultaneously from large colonies and form small floating aggregates. Further these aggregates were collected and transferred in new plates where they were cultured for 2 weeks forming adherent or floating three dimensional follicle-like structures. The expression of growth differentiation factor 9 (Gdf-9), which is required for ovarian folliculogenesis, was observed between d16 and d22. Floating folliclelike structures collected at d26 did not express Gdf-9 indicating that follicular growth was completed. Two of three zona pellucida (ZP) proteins ZP2 and ZP3 were detected between $\mathrm{d} 16$ and $\mathrm{d} 30$. The lack of ZP1 expression could be because of thin and fragile zona of the ESderived oocytes. Blastocyst-like structures were found at about $\mathrm{d} 43$, suggesting spontaneous parthenogenetic activation. These structures expressed a set of stage-specific molecular trophectodermal markers, such as Hand1, Pl-1, Mash-2 and TpBp. Morulae-like structures showed signal of Oct-4 protein with appropriate nuclear localization, which differs from GC where Oct-4 localizes in the cytoplasm (Hübner et al., 2003; Salvador et al., 2008). Native $\mathrm{mES}$ cells $(\mathrm{XY})$ without any genetic modification also were able to produce putative oocytes. The EB were obtained and cultivated adherent on the plastic dish, in a testicular cells conditioned medium, once testis of newborn males contain most growth factors required for the transformation of germ stem cells into differentiated GC. At about 2 weeks oocyte-like cells surrounded by one to two layers of flattened cells were obtained, which expressed 
Vasa protein as well as Oct4, Dazl and Stella. Although they did not have visible pellucid zone, a structural hallmark of maturing oocytes, the expression of oocyte-specific markers, such as Fig-a, Stra-8 and ZP3 were detected (Lacham-Kaplan et al., 2006; Quing et al., 2007). Novak and colleagues (2006) induced differentiation of native ES cells toward female GC by their cultivation in ES cells culture medium without LIF and MEF. Under such conditions EB were formed around d7. These EB produced cells of variable morphology, which after detaching from EB form floating aggregates. Follicle-like structures derived from the aggregates were observed from day 18 and afterward, which expressed several oocytespecific markers.

Our group contributed to these studies demonstrating that male ES cells can generate both female and male (described below) presumptive GC and gametes (Kerkis et al., 2007). In contrast to previous studies, which used the same ES cells basal culture medium, we used serum-free B27/neurobasal medium for differentiation. This medium supported the growth and long-term viability of nearly pure populations of neural cells without the need of any feeder layer. It contains hormones in its composition, which can enhance differentiation process. Thus, we suggested that serum-free B27/neurobasal medium can provide additional advantages. First, the EB were obtained by hanging drop technique in ES cells basal culture medium. Further, they were transferred into serum-free B27/neurobasal medium supplemented with RA. Under such conditions non adherent EB were cultivated for additional 4 days. RA was removed and the cells were further maintained in serum-free B27/neurobasal medium. After 9 days floating EB started to aggregate. The structure composed by several EB underwent further differentiation and within 10-15 days inside EB aggregates the formation of follicular-like structures and of presumptive germinal vesicle has occurred. Floating oocyte-like structures were also found and they expressed Dazl protein, which is overexpressed in normal oocyte during GV-MI-MII (Assou et al., 2006). Although we did not expect to observe spontaneous in vitro fertilization of the oocyte-like structure by the presumptive sperm cells, both formed in the same Petri dish during the process of differentiation, we could identify structures resembling fertilized oocyte with two pronuclei. These "fertilized" oocytes underwent further development into morulae, blastocyst-like structures with well defined but fragile zona pellucida, and hatching blastocyst-like structures. The expression of the genes Gdf9, Zp2, and Zp3, which are indicative for female GC differentiation, was detected. In accordance to Hübner et al., (2003), Zp1 did not express in those structures. For about 25 days, the blastocyst-like structures, attached on the monolayer of differentiating ES cells and formed the cell layer resembling trophoblasts with inner cell mass. This supposed pre-embryo expressed Oct-4 in the inner cell mass-like cells (inside), while trophoblast-like cells (outside) expressed Mash-2 (mammalian achaete-scute homologous protein-2) protein, which is specific for extraembryonic trophoblast lineage (Fig. 5). It is worth mention, that estradiol ( 189.0 $\mathrm{pg} / \mathrm{ml}$ ) was found in culture medium used for ES cells differentiation. It is not included in serum-free B27/neurobasal medium composition, suggesting that it was produced by differentiated GC. Hübner et al., (2003), also reported estradiol production (50-100 pg/ml) after 12 days in mES cell cultures that generated follicle-like structures.

\subsubsection{Derivation of male GC and artificial gametes}

In order to produce male GC from mES cells Toyooka et al., (2003) generated knock-in mES cells, in which GFP or lacZ was expressed from the endogenous mouse vasa homolog (Mvh), which is specifically expressed in differentiating GC. The EB formation occurred 


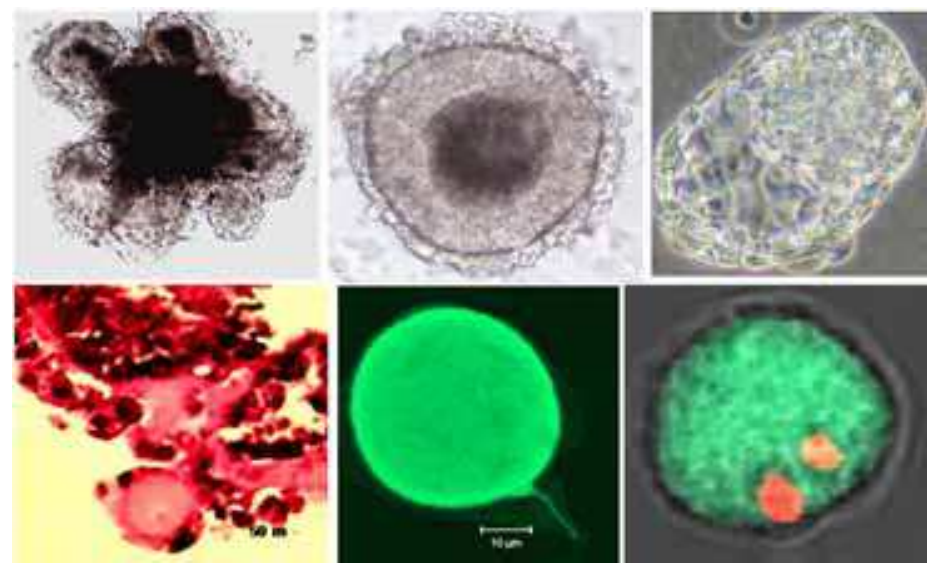

Fig. 5. Female GC development (follicle-, oocyte-, blastocyst- and zygote-like).

when these cells were cultivated in suspension in a LIF-free medium. The knock-in cells, which expressed the reporter gene products clustered together at the periphery of the EB by days 5-7. The $\mathrm{Mvh}^{+}$cells purified (flow cytometry) from EB were equivalent to in vivo fetal gonad GC. Then, Mvh+ cells were aggregated within male genital ridge cells of wild-type embryos. Following implantation into adult mouse testis, the cell aggregates composed by $\mathrm{Mvh}^{+}$positive cells undergo further maturation, formed seminiferous tubules-like structures that have a capacity to support complete spermatogenesis and to produce mature putative sperm cells. Additionally, the authors also found that the exposure of EB to Bmp4 led to the emergence of $\mathrm{Mvh}^{+}$cells within 24 hours. Although the ability of spermatozoa to activate eggs was not examined, this study suggested that the germ line specification and the emergence of postmigratory PGC can occur spontaneously or be induced in EB, which can be completed in testis environment. Geijsen et al., (2004) isolated GC from male ES cells carrying EGFP reporter gene. The EB were produced in basal medium and after 7 days of cultivating, RA was added for additional 5 days. After RA removal the EB were collected by day 20-22. The FEJ1 antibody (Fenderson et al., 1984) was used in order to identify haploid round-spermatid-like cells. The positive cells for this marker and EGFP+ were further selected by flow cytometry and intracytoplasmatic injection into recipient oocytes was performed. These presumptive GC were capable of generating diploid blastocysts, which did not undergo further development. Although the isolated cells did not produce cells resembling spermatozoa and analyses of further embryonic development was not complete, this study suggested that male PGC aroused from ES cells can become postmeiotic cells capable of eggs activating. Nayernia et al., (2006) reported not only the induction of male gametes from ES cells but also the production of offspring; however this work should be carefully evaluated (Daley, 2007). They modified genetically ES cells in order to obtain spermatogonial stem cells (SSC). First, they introduced a promoter (Stra8) active in early male GC linked to a marker gene encoding EGFP. The selected cell population $\mathrm{Stra}^{+} / \mathrm{EGFP}^{+}$already had the characteristics of male PGC ready to enter the initial stages of meiosis. In order to enrich this cell population the cells were further cultivated for 10 days in the presence of RA and 8-10 weeks in RA-free culture medium. Next RA was added 12 hours following selection of EGFP cells. Then authors performed another round of selection by introducing the promoter of a gene expressed in more mature haploid male GC (Prm1) 
linked to another fluorescence marker gene, dsRED. Two genetically modified SSC cell lines were established and designated as SSC7 and SSC12. For differentiation, the cells were cultured on gelatine-coated dishes, without LIF. The appearance of red fluorescent cells suggested that the emerging haploid cells had undergone the final stages of spermatogenesis. Nayernia et al., (2006) claimed that they established SSC cell lines that undergo meiosis and produce male gametes after only $72 \mathrm{hr}$. The shape of the resulting sperm was, however, abnormal. They injected these presumptive sperm cells into eggs. When the resulting 65 embryos were transferred to surrogate mothers, seven live pups carrying the Prm1-reporter gene were derived, which apparently had growth abnormalities and died short time after birth. Certainly, the production of progeny needs to be confirmed by other laboratories.

We demonstrated generation of male GC from XY ES cells without the use of any genetic modification or pre-selection (Kerkis et al., 2007). In our experiments the spermatogenesis like process took place between 9 and 11 days: EB were obtained using "hanging drop" by day 3, then they were kept floating and RA was added for additional 4 days. During this period we already observed migration of presumptive PGC from EB surface and formation of aggregates composed by different cell types, such as spermatogonia, spermatocytes, spermatids and sperm-like cells between 9 and 11 days. We described that gamete-like cell formation occurred in the correct manner based on the expression of early and late GC specific genes, such as Oct-4, Mvh, Stella, Dazl, Piwil 2, Pdrd 1, Rex 14, Rnf 17, Bmp8b, Acrosin, Stra-8, Haprin, LH-R, Gdf9, Zp3, Zp2, Sycp1 and Sycp3. Our immunofluorescence analysis of morphologically well-formed GC and presumptive gametes showed positive labeling with SSEA-1, Oct-4, EMA-1, FE-J1, Dazl, Fragilis, Mvh, Acrosin, and acetylated atubulin (Fig. 6).

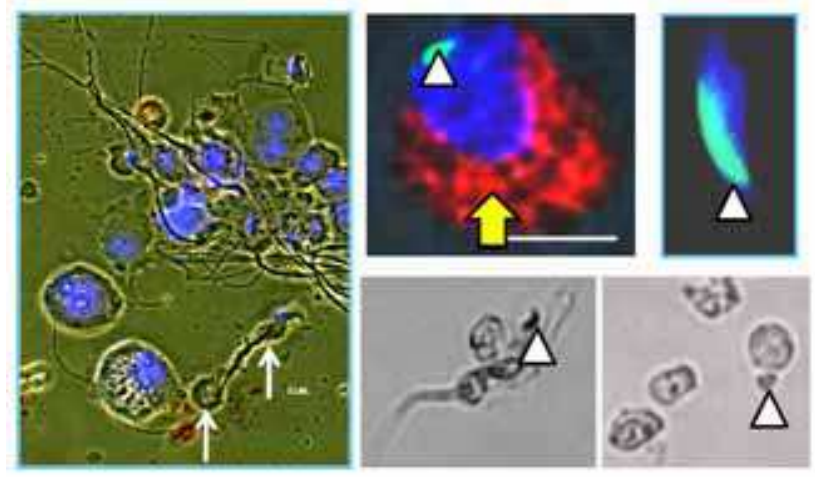

Fig. 6. Morphological aspect of male GC formation and immunocytochemistry analyses for acrosin (green) and alpha-tubulin (red).

Routine cytogenetic analysis demonstrated that GC were able to undergo chromosome reduction, since diploid and haploid chromosome plates were detected. Moreover, we presented undiscussable proofs of sperm-like cells formation in vitro, which are morphologically similar to normal ones. Electron microscopy images showed acrosomal phase of differentiation, which presented by elongated and flattened nucleus, acrosomal granule has become the acrosome and it follows the shape of the nucleus, tail filaments called axoneme further elongate and mitochondria aggregate about the axoneme cytoplasm 
is moved by a cylindrical sheath of microtubules called the manchette in the area of the developing tail. At maturation phase, we observed final formation of sperm and residual body (Fig. 7).

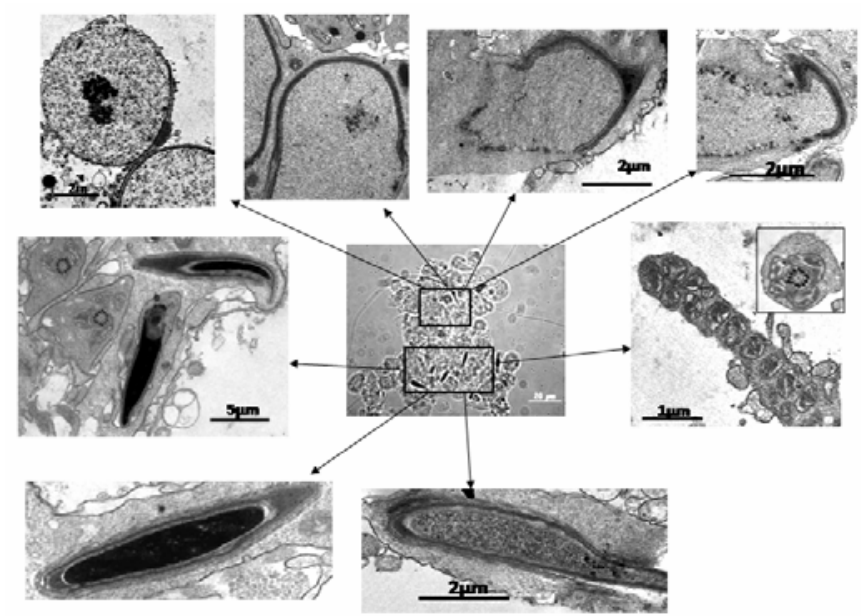

Fig. 7. Transmission electron microscopy of male GC formation.

\subsubsection{Fate determination during XY ES cells differentiation into GC}

During murine and human ES cells culture, markers of female GC are expressed in both XX and XY cell lines (Toyooka et al., 2003, Hübner et al., 2003; Geijsen et al., 2004, Clark et al., 2004; Nayernia et al., 2006: Kerkis et al., 2007; Lavagnolli et al., 2009). Previous studies involving $X X \leftrightarrow X Y$ mouse chimeras have shown that GC whether $X X$ or $X Y$ were able to enter meiosis in developing ovary, but not in testis, suggesting that initial sex determination depends on environment rather than on chromosome composition (Palmer and Burgoyne, 1991; McLaren, 2003). For that reason, both male and female ES cell lines can display female germ cell markers, since culture conditions may be sub-optimal and lack meiosis inhibition. Recently it has been shown, that GC in order to enter meiosis responds to the external signal of RA and its metabolism, (Bowles et al. 2006, Koubova et al., 2006). Thus, in the embryonic mouse ovary, RA induces germ cells to express the pre-meiotic marker Stra-8 (stimulated by) retinoic acid and initiate meiosis. By contrast, in the embryonic mouse testis, RA is metabolised and inactivated by the P450 enzyme CYP26 (B1) thereby preventing early germ cell entry into meiosis with down-regulation of genes such as SCP3 (synaptonemal complex protein; associated with meiotic events). Therefore, the induction of presumptive PGC into meiosis in culture medium containing RA might be expected although local concentrations within cell aggregates may differ significantly and affect the timing. However, the sensitivity of cells to RA can vary considerably depending on composition of medium.

\section{Putative male and female GC and artificial gametes derived from mouse reprogrammed cells}

Cell fusion between embryonic stem (ES) and somatic cells usually yields ES-somatic cell hybrids (ES-SCH), which retain pluripotency in spite of the presence of "somatic" chromosomes in their genomes (Fig. 8). These reprogrammed near-diploid ES-SCH shows a 
developmental potential similar to ES cells: they express molecular ES cell markers, present reactivation of the $\mathrm{X}$ chromosome, form $\mathrm{EB}$ in vitro and produce chimeras with contribution to different tissues (Mittmann et al., 2002; Vasilkova et al., 2007).

Our group was the first to show that reprogrammed cells obtained from the fusion of mES cells and mouse splenocyte were also able to undergo GC differentiation in vitro (Lavagnolli et al., 2009). Differentiation of ES-SCH was induced through EB formation and by the addition of retinoic acid following previously described protocol (Kerkis et al., 2007). Presumptive GC obtained reacted positively with anti-EMA, Vasa, Fragilis and Dazl antibodies and expressed GC-specific genes, such as Vasa, Stella, Dazl, Piwil2, Tex14, Bmp8b, Tdrd1 and Rnf17. Fluorescent in situ hybridization analysis (FISH) indicates chromosome reduction in the GC-like cells. Expression of meiotic and postmeiotic GCspecific genes such as Haprin, Acrosin, SYCP1, SYCP3 and Stra-8 was also detected. Transmission electron microscopy confirmed ES-SCH differentiation into presumptive GC. The presence of several autosomes and the X chromosome originated from the "somatic" partner did not prevent ES-SCH differentiation towards presumptive GC. Overall our study suggests an interesting in vitro model, which allows the study of GC differentiation in reprogrammed somatic cells. This study represents significant advance, showing future prospect to obtain partly patient-matched GC and gametes.

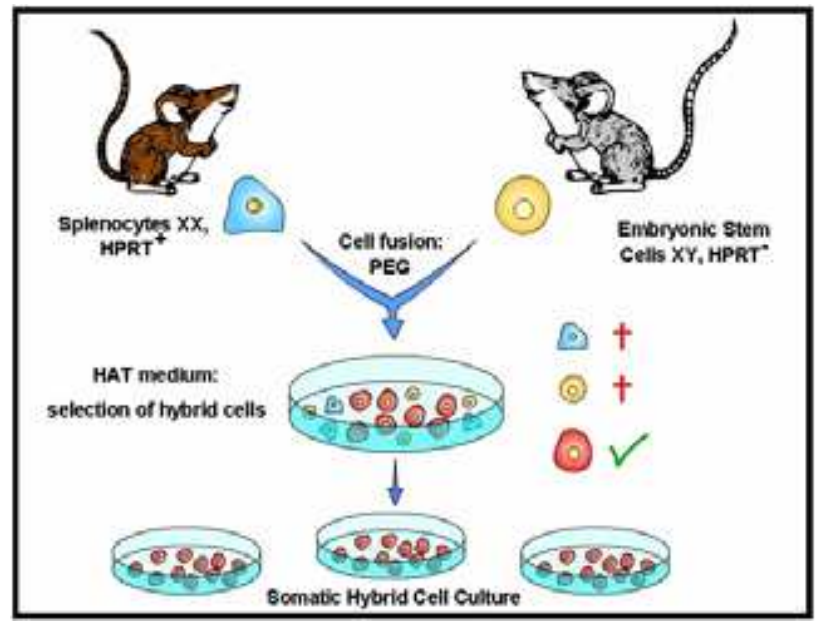

Fig. 8. Somatic cells reprogramming by fusion

\section{Putative GC derived from $\mathrm{hES}$ and induced pluripotent stem cells}

The ability of hES cells to enter the germ line was examined by Clark and colleagues (2004). This and further studies, based mainly on molecular analysis of stage specific genes expression, suggested that hES cells of both sexes may spontaneously through EB formation generate presumptive GC and supposedly undergo meiosis (Clark et al., 2004, Aflatoonian et al., 2005). More recently other groups improved previous protocol by the addition of growth factor in order to improve GC differentiation within the EB (Kee et al., 2006; Tilgner et al., 2008; West et al., 2008; Park et al., 2009). The molecular analysis revealed the expression of the germ-line stage-specific genes (e.g., VASA, DAZL) and of the meiotic 
marker (SYCP3). However, expression of germ-line stage-specific proteins was only marginally studied (West et al., 2008, 2010). Until now, only two studies showed the image of follicular-like structures appearing within monolayer or EB of differentiated ES cells whose morphology resemble those of normal oocytes (Chen et al., 2007; Aflatoonian et al., 2009). The first study did not present any evidences if they do indeed oocytes-like structures (Chen et al., 2007), while other failed to detect expression of ZP proteins in these structures (Aflatoonian et al., 2009). Induced pluripotent stem (iPS) cells are differentiated somatic cells reverted to a pluripotent state. After reprogramming, they acquire properties of ES cells in morphology, proliferation, gene expression, epigenetic profile, and differentiation potential (Takahashi \& Yamanaka, 2006, Takahashi et al., 2007). This approach would allow the creation of patient-specific cells, which is advantageous for cell therapy due to immune compatibility. The derivation of GC from human (h)iPS cells constitutes both a desirable model for reproductive geneticists, and a potential method for treating couples with infertility due to germ cell defects. It has been shown that derivation of GC from (h)iPS cells following 7 days of differentiation results in the generation of immature GC corresponding to a developmental stage in vivo between specification and less than 9 weeks of gestation (Park et al., 2009). However, the doubts about the usefulness of (h)iPS cells for GC generation raised by the study of massive epigenome reorganization. It was unclear whether reprogramming of female human cells reactivates the inactive $X$ chromosome $(\mathrm{Xi})$, as in mouse. In order to clarify this question, (h)iPS cells were derived from several female fibroblasts under standard culture conditions carrying a Xi. These cells showed the lack of Xi reactivation. This finding critically implicates with the use of (h)iPS cells for clinical applications and disease modelling, and could be exploited for a unique form of gene therapy for X-linked diseases (Tchieu et al., 2010). Furthermore, (h)iPS and hES are distinguished by gene expression signatures (Chin et al., 2009). Overall, the methodologies of hES cells derived presumptive GC and gametes characterization are often limited to molecular profile of genes expression involved in GC specification leaving aside the other important characteristics. Therefore, derivation of GC from hES and (h)iPS cells is still at initial stage.

\section{Timing of in vitro ES-derived GC differentiation}

The genes involved in the differentiation of the three germ layers, and genes specific for several cell lineages are expressed in EB over the same time period as in gastrulating embryos. In contrast, all studies showed that derivation of GC from ES cells takes place much faster in vitro than in vivo. Several studies showed that ES cells in culture have already acquired the capacity to form PGC expressing a set of PGC genes in undifferentiated state e.g. PGC founder-specific genes Stella and Fragillis are detectable in ES cells before the onset of differentiation, whereas those genes are not expressed in the inner cell mass and early epiblast cells in vivo (Aflatoonian and Moore, 2006; Ko \& Schöler, 2006; Nagano., 2007; Daley, 2007; Hua and Sidhu, 2008; Marques-Mari, 2009). The environmental factor can also influence the timing of differentiation, therefore progression of PGC differentiation may be suppressed in the embryonic environment until the PGC reach an appropriate position near the developing gonads. Additionally, some of the factors that regulate the timing of PGC differentiation in the embryo are absent from in vitro culture systems. The discrepancies in timing observed in different studies may be related with properties of ES cell lines and culture conditions used in each work. 


\section{Molecular characterization of putative GC}

Independently of the methodologies of ES cells differentiation toward GC, the molecular characterization is indispensable. Using simple or sophisticated methods, the studies need to show an expression of PGC markers (specification and specific gametogenesis) during development of both types of gametes. Understanding of PGC molecular mechanisms of differentiation and fate is important to elucidate infertility causes. The molecular analyses are an important tool to characterize this complex process, which is necessary not only to confirm a success of applied protocol, but also to evaluate their efficiency and effectiveness. In table 1 we summarized information about genes markers for different stages of gametogenesis used in different studies. A careful study of in vitro PGC specification is difficult by the fact that mammalian in vivo or in vitro cultured PGC derived from native tissues and ES cells shared a significant number of markers e.g. Oct4 and SSEA1. In addition, PGC markers, such as Blimp1, Mvh, Fragillis and Stella and even GC markers, such as Piwil2, Rnh2, Tdrd1 and Tex14, are also detected in undifferentiated ES cells. Among these markers Stella was appointed as an excellent marker to be used for cell sorting of GC in vitro (Wei et al., 2008). A systematic analysis of single cell showed a gene expression dynamics in GC line during PGC specification in vivo and revealed differential pattern of several genes expression between ES cells and PGC e.g. Eras, T and Fgf8 (Yabuta et al., 2006). A core of genes as Oct4, Sox2, and Nanog which regulates pluripotency in stem cells also performs an important role in GC development regulation. The repression of this core machinery regulating pluripotency is an early event involved in differentiation of GC. Furthermore, in mice fetal male-specific germ line methylation of functional elements as Nanog and Sox2 promoters and genes was shown suppressed during early male GC differentiation. The Oct4 translation is suppressed post-transcriptionally following male GC differentiation allowing entrance in the mitotic arrest (Western et al., 2010). Therefore, the determination of single cell PGC and GC molecular markers in a challenge for the future studies will allow improving currently established protocols of both GC derivations from appropriate tissues and from ES cells in vitro.

\begin{tabular}{|c|c|c|c|c|c|c|c|c|}
\hline Specification & & & & & & & & \\
\hline Blimp1 & & & & & & & & - \\
\hline Bmp8b & & a & & & & & - & \\
\hline C-kit & - & & & & - & ma & & - \\
\hline Ddx4 & & & & & - & & & \\
\hline eFgls & & - & - & & - & & 口 & \\
\hline Fgf8 & & & & & & & & $\square$ \\
\hline Nanog & & & & & & & & घ \\
\hline Oct4 & - & घ & घ & - & - & m & m & $\square$ \\
\hline Piwil2 & & & ! & & - & & - & \\
\hline Rbm & & & & & -1! & & & \\
\hline Rnf17 & & & घ & & - & & घ & \\
\hline Rnh2 & & & घ & & & & & \\
\hline Sox 2 & & & & & & & & $\square$ \\
\hline
\end{tabular}




\begin{tabular}{|c|c|c|c|c|c|c|c|}
\hline Sox17 & & & & & & & $\square$ \\
\hline Stella & - & - & & - & - & घ & घ \\
\hline Tdrd1 & & - & & & & घ & \\
\hline Tex14 & & - & & & & घ & \\
\hline SSEA1 & & - & . & & & I & \\
\hline
\end{tabular}

\begin{tabular}{l|l|l|l|l|l|l|l|l|l|} 
Studies & 1 & 2 & 3 & 4 & 5 & 6 & 7 & 8
\end{tabular}

\begin{tabular}{|c|c|c|c|c|c|c|c|}
\hline Gamete determination & & & & & & & \\
\hline Dazl & & & - & - & - & $\square$ & \\
\hline Stra8 & & & & $\square$ & - & - & \\
\hline Vasa (Mvh) & $\square$ & $\square$ & & - & $\square$ & घ! & - \\
\hline
\end{tabular}

\begin{tabular}{|c|c|c|c|c|c|c|c|}
\hline Gametogenesis & & & & & & & \\
\hline Acrosin & & & & & - & & m \\
\hline Acetylated a-tubulin & & & & & & & घ \\
\hline Dmc1 & - & & & & - & & \\
\hline DsRed (condesen Nuclei) & & & & & - & & \\
\hline Ema-1 & & & & & & & - \\
\hline FE-j1 & & & - & & & & - \\
\hline Figa & & & & & & - & \\
\hline Gcna1 (Meiosis) & & - & & & & & \\
\hline Genf & & & - & & & & \\
\hline Gdf9 & घ & & & & & & a \\
\hline Haprin & & & - & & & & - \\
\hline hnRNPGT (sperm meiosis) & & & & & - & & \\
\hline Hsp90a & & & & & - & & \\
\hline Oam (sperm pos meiotic) & & & & & - & & \\
\hline Prm1 (Pos Meiotic) & & & & & - & & \\
\hline Rec8 (Meiosis) & & & & - & & & \\
\hline Scp1 (Meiosis) & & & & - & & & - \\
\hline Scp2 (Meiosis) & & & & - & & & \\
\hline Scp3 (Meiosis) & ma & - & & - & - & & - \\
\hline Smc1- $\beta$ (Meiosis) & & & & घ & & & \\
\hline Stag3 (Meiosis) & & & & घ & & & \\
\hline Tp2 (Pos Meiotic) ${ }^{* * *}$ & & & & & घ! & & \\
\hline Zp1 & & & - & & & - & - \\
\hline $\mathrm{Zp2}$ & - & & - & & & - & ! \\
\hline Zp3 & & & - & & & - & - \\
\hline
\end{tabular}

- RT-PCR = Immunoassay

1- Hübner et al. (2003); 2 - Toyooka et al. (2003); 3 - Geijsen et al. (2004); 4 - Novak et al. (2006),

5 - Nayernia et al. (2006); 6 - Lacham-Kaplan \& Trounson (2006); 7 - Kerkis et al. (2007), 8 - Wei et al. (2008).

Table 1. Markers of GC differentiation. 


\section{Epigenetic modifications of ES derived GC}

An important emerging theme from recent studies is that epigenetic modification can be implicated in GC development itself, contributing to the gene expression program that is required for GC development, regulation of meiosis and genomic integrity. Understanding of epigenetic regulation in GC has implications for reproductive engineering technologies and human health.

Epigenetics has been defined as a collection of mechanisms and phenomena that will generate the phenotype without affect the genotype. The mechanisms involved in this regulation are represented by a range of chromatin modifications, including DNA methylation, histone modifications, remodelling of nucleosomes and higher order chromatin reorganization. These epigenetic modifications define a cellular identity regulating gene expression and are unique in each cell. Epigenetic profiles are adjustable during cellular differentiation, but remains inherited: it ensures that daughter cells have the same phenotype as the parental cell (Goldberg et al., 2007).

The process of GC development is regulated by both genetic and epigenetic mechanisms. This type of cell can give rise to a new organism. Therefore, during fertilization, the products of GC development - the oocyte and sperm cell, fuse to form a zygote, which is considered totipotent. To acquire this totipotency, the GC and the zygote undergo to extensive epigenetic reprogramming. In mammalian GC, reprogramming also erasure the existing parental imprints and establishes new ones, which are different in male and female gametes. Genomic imprinting gives rise to differential expression of paternally and maternally inherited alleles of certain genes. Thus, unlike most genes in our genome, which are either expressed or silenced from both parentally inherited alleles (biallelic expression), monoallelic expression of imprinted genes occurs in a tissue and developmental stagespecific manner during development (Allegrucci et al., 2005; Reik, 2007). Imprinted genes comprise a small subset of the genome, perhaps 100 out of the total 30000 genes whose epigenetic reprogramming in the germ line is imperative for subsequent normal development of the embryo (Miozzo \& Simoni, 2002). Almost all these imprinted genes could be used as a strategy to confirm the potential status of GC differentiation.

The role of epigenetics in GC and in somatic cells occurs in different way. During somatic cell differentiation, cells initiate in a pluripotent state followed by decision of their fate, being able to originate a range of different cell types (Reik, 2007). Their gene-expression profile become more restricted and potentially protected from epigenetic modifications. On the other hand, GC are different in that, because their fate has been determined during early development. The GC have specific fate suffering a series of epigenetic events that are unique to this cell type. GC undergo meiosis and the particular importance of maintaining genomic integrity. It is important to study how imprints are re-established in the male and female GC and their contributions to GC-specific functions at each stage.

Recent studies have shown that changes in epigenetic modifications also have important roles in the regulation of post-migratory PGC-specific genes. Genes such as Ddx4 (also known as Mvh), Sycp3 (synaptonemal complex protein 3) and Dazl (deleted in azoospermia-like) are induced after migrating of PGC toward genital ridge. DNAmethylation analysis revealed that, despite the genome-wide decrease in DNA methylation after E8.0, the flanking regions of these genes remain methylated at E10.5, but become hypomethylated by E13.5 when they are expressed. The results suggest that DNA methylation regulates the timing of activation of these genes. In mice, when PGC arrive at 
the genital ridge (E11.5), they undergo extensive epigenetic reprogramming, including the erasure of parental imprints. The erasure of imprints is reflected by demethylation of the imprinted loci, which occurs concomitantly with demethylation of other regions. Once the parental imprints have been erased, new imprints must be re-established according to the gender. This re-establishment occurs only after sex determination has been initiated, and male and female GC development diverges to give rise to sperm or oocytes, respectively (review in Sasaki \& Matsui, 2008). It should be considered the GC formation from ES cells.

Another important event that occurs in mammalian female cells is the X-chromosome inactivation. In somatic cells of female mammals, one of the two $X$ chromosomes is inactivated so that the dosage of the genes on this chromosome is equalized between males and females. The inactive X chromosome is reactivated during female GC development. Extensive studies have been made to understand when this mechanism occurs and how they can be maintained by the generation. It had been thought that this reactivation occurs around the time of imprint erasure (Monk \& McLaren, 1981; Tam et al., 1994) However, more recent studies showed that it is initiated in the migratory stage (de Napoles et al., 2007) or at an even earlier stage (Sugimoto \& Abe, 2007). Therefore, X-chromosome reactivation occurs in a progressive manner in prolonged period and is completed in post-migratory PGC.

Geijsen et al., (2004) showed in their experiments haploid round spermatids displayed somatic-like imprinting status of the Igf2r and H19 genes by day 4 of differentiation. The imprinting methylation profile was erased by day 7, demonstrating that the PGC derived from EB may be able to mimic the epigenetic reprogramming features of PGC developing in vivo. Nayernia et al., (2006) obtained sperm cells, which were able to fertilize oocytes after ICSI resulting in a number of pregnancies, although the majority died in uterus, the others development to term. The resultant pups, however, had abnormalities in DNA methylation at imprinted loci and survived only up to five months, indicating that reprogramming of the GC genome was not properly accomplished.

Recently, Kee et al., (2009) explored adherent differentiation of human ES cells carrying VASA-GFP reporter in the medium supplemented with or without BMP4, and observed that both XY- and XX-bearing human ES cells (approximately $0.8-5 \%$ ) reproducibly gave rise to PGC. The epigenetic status was analyzed and showed erasure of methylation (hypomethylation) globally and at the differentially methylated regions (DMRs) of imprinted loci. The authors found that the H19 locus was hypomethylated in GFP1 cells relative to GFP2 cells. Results from other imprinted loci (PEG1/MEST, SNRPN, and KCNQ) confirmed that the GFP1 cells also showed significantly lower levels of methylation at these DMRs relative to other cell types. Furthermore, examination of global DNA methylation levels provided strong evidence that the VASA-GFP1 population was in the process of erasing methylation globally. When DAZL and BOULE were overexpressed in XX human ES cells, PGC formation was enhanced suggesting potential formation of haploid gametes. Regarding to iPS cells, Park e co-workers (2009) showed that VASA expressed during germ cell formation in the first trimester of human development in vivo. They used these surface markers to isolate putative (h)iPGC from hES cells and (h)iPS cell lines after differentiation on primary human fetal gonadal stromal (hFGS) cells in vitro. They found that imprinting control center that were differentially methylated in undifferentiated hES cells (H19 and SNRPN in HSF-1 and H19, PEG1, and SNRPN in HSF-6) initiated the process of imprint erasure by day 7 in the iPGC. However, (h)iPGC derived from hIPS cells do not initiate imprint erasure as efficiently. Regarding $\mathrm{Xi}$, these (h)iPGC showed the lack of $\mathrm{Xi}$ 
reactivation. This work suggests that GC originated from iPS cells are not as efficiently as from ES cells in the epigenetic remodelling. If these results will be confirmed by other studies, it could be a barrier in case of therapy of infertility using iPS cells to produce gametes in infertile patients.

When we fully understand the complete mechanisms of germ-cell reprogramming, we might be able to derive appropriately reprogrammed and functional gametes from cultured cells. This will allow new approaches to reproductive engineering, although ethical and safety issues must be carefully considered.

\section{Meiosis in ES derived GC}

The meiotic process is an essential step in the gamete formation in organisms with the system of sexual reproduction and this process is indeed studied inadequately. A better understanding of the meiosis and its regulation, together with advances in genomics, will allow us to predict a perfect establishment of fertility disorders. Meiosis is a cellular division mechanism based on separation and diminishes of the chromosomal set followed by haploid cells formation (gametes). In eukaryotes is characterized by an extended prophase, followed by two divisions. A sexual meiosis dimorphism should be considered: first, in male, one single cell that enters in meiosis can produce four haploids gametes (sperm cell). On the other hand, in the female, one single cell will originate only one gamete (oocyte), which completes second division after the fertilization (Fig. 2).

Meiosis is preceded by DNA replication in a pre-meiotic $S$ phase, usually longer than mitotic $S$ phase. The pre-meiotic DNA replication generates primary gametocytes; each chromosome is comprised of two chromatids (4C DNA content). The S phase is proceeded by the long meiosis I prophase (this phase is divided in other four substages), during which homologous chromosomes starts to be paired and undergo recombination in a series of events that define the substages of meiosis I prophase. This crossing-over (CO) recombination in meiosis is required to guarantee an accurate segregation of homologous chromosomes at the first meiotic division. The absence of $\mathrm{CO}$ can result in random disjunction (separation of chromosomes or chromatids during anaphase of mitosis or meiosis) and might form an aneuploidy gamete, that may leads to embryonic death or developmental abnormalities (review in Handle \& Schimenti, 2010). In fact, aneuploidy present in gametes is a principal cause of birth defects in humans. Most of these aneuploidies are formed during oogenesis, mainly during the first meiotic division, and the frequency of such errors increases with female age (Hassold et al., 2007).

The substages of meiosis I prophase are defined by chromosome configurations and structure: pairing, which occurs during the leptotene and zygotene stages. These events are accompanied by synapsis, a process that is mediated by a specialized meiotic structure, the synaptonemal complex (SC). The recombination structure is defined by the formation of a chiasma (the point that the chromatids of the homologous chromosomes undergo the recombination - exchange). The first meiotic division (metaphase I, followed by anaphase I and telophase I) is reductional and separation homologous chromosomes, producing secondary gametocytes. Each gametocyte has haploid chromosome content in which still comprised of two chromatids). In male gametogenesis, it results in two secondary spermatocytes and in females it results in one secondary oocyte and a polar body. The second meiotic division - an equational division, separates sister chromatids. This phase is also sexually dimorphic, but in this case in both of timing and in the products formed. In 
males it occurs immediately after the first division and the chromatids are separated and produce four haploid immature spermatids that contain the haploid chromosome number and 1C DNA content. In female GC, the timing of the second meiotic division is coordinated with ovulation and occurs after fertilization, producing a haploid oocyte (fertilized egg) that contains two haploid pronuclei, one paternal and the other maternal as well as three polar bodies (review in Handle \& Schimenti, 2010).

Based on the architecture of the meiosis, the chromosome pairing and the $\mathrm{CO}$ are crucial for the appropriate segregation of homologous chromosomes at the first meiotic division of most organisms. The fidelity of recombination and chromosome segregation that avoid aneuploidy are dependent of the dynamics of chromosome pairing and synapsis during meiotic prophase. The chiasma formed by $\mathrm{CO}$ events is essential and we can see the occurrence of at least one $\mathrm{CO}$ per chromosome in humans. This protein structure (lateral elements - LE, cohesin REC3 and axial elements - AE, synaptonemal complex (SC)-specific proteins, such as SYCP3 and SYCP2 formed in the chromosome pairing) can physically maintain chromosome homologues attached during the end of prophase. In this moment, the cohesins are removed and the structure progress to the metaphase I and chromosome homologue division (Fledel-Alon et al., 2009). Failure of a chromosome pairing to undergo at least one $\mathrm{CO}$ can result in both homologues segregating to the same daughter cell at the metaphase I, leading to aneuploidy.

A lot is known about of the proteins that contribute to formation of the chromosomal axes and the SC, but little is known about exactly how the separable events of pairing and synapsis come about, mainly when we consider this events in GC derived from ES cells. Some proteins related with this structure such as SYCP1, SYCP2 or SYCP3, cohesins and the telomere length of the chromosome have been studied to a better understanding of the meiosis process in the GC derived from ES cells. Several reports have demonstrated the formation of oocyte-like structures and postmeiotic male GC in embryonic stem (ES) cells culture (Clark et al., 2004; Geijsen et al., 2004; Hübner et al., 2003; Lachan-Kaplan and Trounson, 2006; Nayernia et al., 2006; Toyooka et al., 2003). Molecular analysis of the expression of these genes required in the initial and progression of the meiosis and the SC formation have been done suggesting that the cell formed in this type of differentiation could be GC in different phases of maturation. But in almost all of these studies the analyses is based on molecular gene profile only or in some cases in immunocytochemistry showing the presence of the proteins involved. According to Novak et al., (2006), the meiotic process in germ cell-like cells derived from ES cells probably fail to correctly initiate and progress due to the absence of complementary meiotic proteins, even though they express SYCP3, indicating that only the molecular expression analysis is not enough to confirm the CG formation and maturation. Their results demonstrated that the SC did not occur efficiently, and the FISH results revealed two separate signals of same chromosome homologue (when the expected are together), which is an indicative of the absence of bivalent formation. This study suggested that the chromosome organization of these cells was associated to a mitotic division instead of meiotic. Resumption of meiotic progress and entry into the meiotic division phase is controlled by somatic cells and in vivo is hormonally prompted (Hsieh et al., 2009). In this case described by Novak, we can suggest that the oocyte-like cells did not progress into meiosis due to the fact that the development observed in vivo are arrested in prophase I of meiosis I until there is a hormone stimulus that triggers their meiosis I accomplishment. We should consider that in their work, it was analyzed a low number of follicle-like structures, that could not represent the remaining cells. Another important thing is that, in vivo in each cycle a lot of primordial follicles were required 
in hormone response, but just one completes the meiosis I, being ovulated. In this work, it might occur and the samples could represent the oocytes that not complete the meiosis phase.

The correct segregating chromosomes in meiosis and formation of a haploid cell is a prerequisite for the derivation of CG from ES cells in both - animal model of study or cellular basement therapy in the treatment of infertility. Our group (Kerkis et al. 2007), which showed the occurrence of both types of cells female and male GC in the same culture conditions. The cytogenetic analyses demonstrated cells with the chromosomes organized in similar manner as during meiosis I. FISH data showed cells with two signals of both $X$ and $Y$ chromosomes, as well as, the cells with only one signal of $\mathrm{X}$ or $\mathrm{Y}$ chromosome in each, indicating that the meiotic process occurred (Fig.9). However, both studies (Novak et al., 2006; Kerkis et al., 2007) are not completely conclusive. Further analyses should be provided to explain the details of meiosis. We need to analyze all aspects of meiosis associating them with epigenetic modifications.

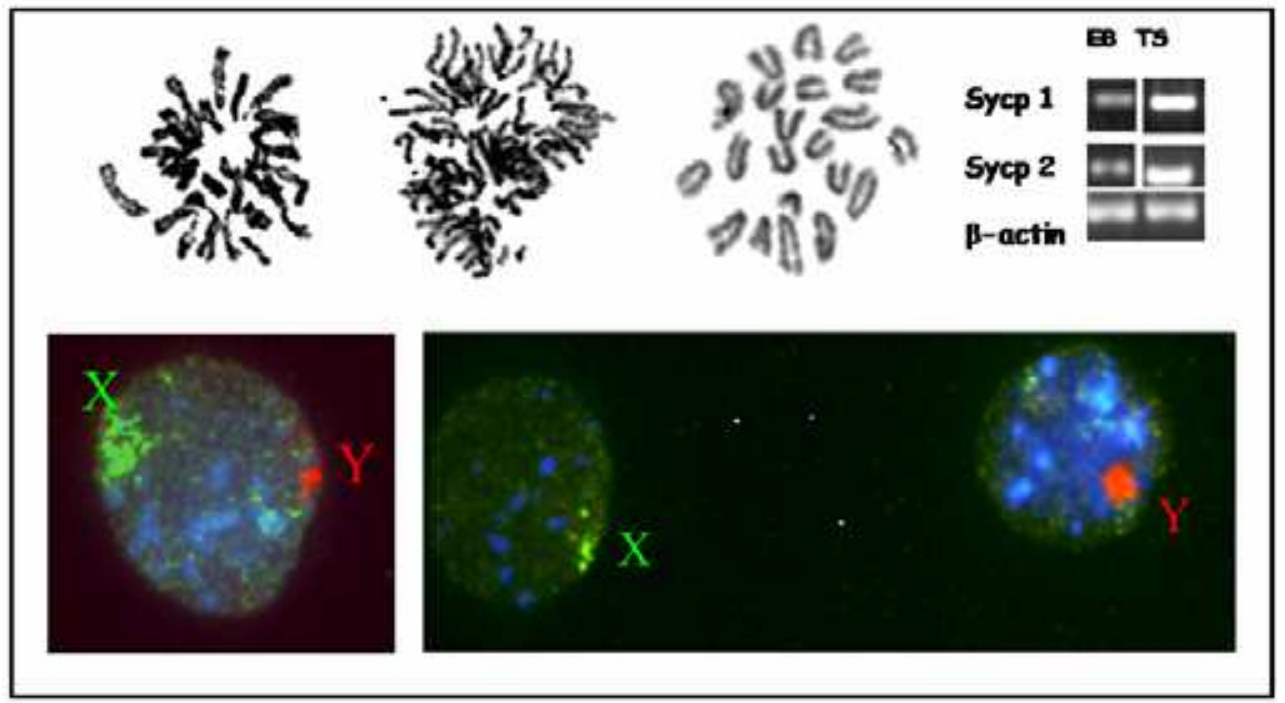

Fig. 9. Meiosis progress during male GC differentiation (conventional cytogenetic, molecular and FISH analyses).

Although, the substantial knowledge of PGC and gamete development in the mouse and many mechanisms are highly conserved in mammals, little is known about human CG formation and there remains necessary to investigate (Moore \& Aflatoonian, 2007), mainly when we consider the differentiation from ES cells. Although PGC development can be formed from these systems, post-meiotic cell phenotypes have been difficult to identify and recover. Recently, Kee et al., (2009) used $\gamma \mathrm{H} 2 \mathrm{AX}$ (indicator of meiotic recombination) and SYCP3 (synaptonemal complex formation in meiotic prophase I) to examine meiotic progression and showed low levels of SYCP3 in rare cells and no signal of $\gamma \mathrm{H} 2 \mathrm{AX}$. These results indicate that these cells were in a pre-meiotic stage, and rare cells entering in meiosis. DNA content analyses by flow sorter showed that less than $2 \%$ of the cells were $1 \mathrm{~N}$ 
(haploid) confirmed by FISH. This percentage of cells that complete meiosis process is consistent with the natural process in vivo.

Several studies have been characterized the transcriptome during male meiosis in mice (Schlecht et al., 2004; Shima et al., 2004), but the regulators of the mammalian meiotic program continuous unidentified. Up to now, the major advance was the discovery that the onset of meiosis in mice is regulated by RA and is mediated by Stra8 (Bowles et al., 2006; Koubova et al., 2006; Bowles \& Koopman, 2007). The effect of RA on Stra8 induction and initiation of meiosis is sexually dimorphic in timing. In fetal ovaries the RA is secreted by the mesonephroi and can induce the Stra8 expression and the GC enter in meiosis. These events can be detected by waves of expression of meiotic markers, for example: Dmc1 (disrupted meiotic cDNA 1 homologue) and Sycp3. The fetal testis are also exposed to RA, but the Stra8 expression is not induced because the presence of a CyP26B1 and P450 family. This gene is expressed only in Sertoli cells with consequence of male GC do not enter meiosis during the fetal life; the entry of GC into meiosis in the adult testis appears to be controlled, at least in part, by stage specific expression of CyP26B1. The role of STRA8 and $\mathrm{RA}$ in the regulatory process of the meiotic initiation in both spermatogenesis and oogenesis was confirmed by genetic analysis (Anderson et al., 2008). The regulation of meiotic initiation by RA could involve germ cell intrinsic factors, such as the RNA binding protein DAZL (deleted in azoospermia-like), which may act upstream of Stra8 in the pathway of meiotic induction (Lin et al., 2008).

Based on these results, the presence of RA and expression of STRA8 and possible the DAZL are necessary for the entry of GC in the meiosis in different times of life. In almost all works published showing the derivation of germ cell from mES cells have been demonstrated a molecular profile of gene expression and in almost all of them, the presence of RA in the cell culture is totally necessary for the meiotic progress (review in Kerkis et al., 2007). Nayernia and co-workers (2006) developed SSC lines from ES cells able to undergo meiosis and capable to generate a functional haploid male gametes in vitro. The authors demonstrated the increasing of the expression of Stra8 after the addition of RA in culture. A FACS analysis showed that approximately $30 \%$ of these cells undergo meiosis and produce a haploid cell population after $72 \mathrm{hr}$ of RA induction that was not observed in culture without RA induction. The authors showed the formation of SC after electron microscopy analyses. Lacham-Kaplan and Trounson (2006) reported the formation of putative oocytes by using testicular cells conditioned medium. We showed both types of differentiation, male and female CG (Kerkis et al., 2007) in the same culture condition by RA induction. Our results demonstrated an increase of gene expression after RA induction and the expression of meiosis markers.

Finally, much effort has been devoted recently to the generation of functional gametes from embryonic stem cells or iPS cells. We should consider that mammalian GC are surrounded by specialized somatic cells (Sertoli cells and granulosa cells) in which secrete substances that influence their homeostasis and meiotic status. For these reasons, it has not been completely possible to successfully sustain initiation and continuous execution of all steps of meiosis in vitro. In any attempt to generate mammalian gametes in vitro, it will be challenging to mimic the roles of the somatic cells that act in both instructive and permissive roles to support meiosis and gametogenesis. Any use of in vitro derived mammalian gametes must be predicated on rigorous proof of the execution of key steps in meiosis and the fidelity of chromosome segregation. 


\section{Functional status of artificial gametes}

The gametes are a key for conservation and preservation of the species (Hua \& Shidu, 2008). The haploid DNA, generated on gametogenesis, will be joined by fertilization to develop a new individual. Due to the importance of this event, the gametogenesis is a complex and regulated process, difficult to be mimicked in vitro (Daley, 2009). Spermatogenesis involves mitosis, meiosis, spermiogenesis and spermiation, a cascade of events that must occur precisely and with the involvement of the Sertoli cells (Wong \& Cheng, 2009). After leaving the testis, the sperm pass through the epididymis, formed by a pseudo-stratified epithelium with several cell types (Cornwall, 2009) and a specific and specialized condition is created. The changes in the spermatozoa arising from active secretion and absorption of water, ions, organic solutes and proteins, beyond the function of maintaining blood barrier. Besides the changes, epididymal secretions maintains the vitality of the sperm, allowing the development of motility and protect against harmful agents (Robaire et al., 2006), essential for complete maturation of sperm, which involves the development of progressive motility the ability to recognize, bind and penetrate the oocyte (Moore, 1990). These modifications include changes in composition and biophysical properties of the sperm membrane, stabilization of chromatin and other organelles with disulfide bridges, as well as morphological changes such as the migration of cytoplasmic droplets (Bassols et al., 2005). One mature sperm is mobile, able to perform the fertilization process and support the development of a new individual. The maturity of gametes differentiation in vitro was hardly questioned (Daley, 2007). Several groups have succeeded in obtaining sperm-like cells in different conditions. None of them showed typical progressive motility and nobody known whether the culture conditions and differentiation in vitro causes any change such as occurs in vivo in the epididymis. In contrast with other studies, we obtained mature sperm cells (Fig. 6 and 7); however we also did not succeed to register any sperm motility (Kerkis et al., 2007). Embryos (Geijsen et al., 2004) and pups (Nayernia et al., 2006) performed by ICSI using sperm-like cells derived in vitro, died quickly, demonstrating that this process still have failures. Another important point to consider is the efficiency of gamete production in vitro. Rare sperm-like cells are generated, regardless of culture condition and genetic manipulation.

\section{Conclusions}

Infertile couples caused by genetic and epigenetic or any other problems which requires chemotherapy or radiotherapy, justify the challenge to enlarge our knowledge about the complex gametogenesis process and develop diagnostic approaches; gene therapies and any other techniques for fertility preservation and treatment. Only the first's steps were taken. The knowledge produced can be used to better understand this complex process - the gametogenesis and help these couples studying the failures. Now, we should focus on increasing the efficacy of the process and better characterize the cell types produced. In animals, is possible to test the functionality of these cells, and see how close the differentiation process is from normal. Then, it will be possible to test male contraceptive drugs evaluating the toxicity effects of new drugs on the germinal tissue. Another side of this promising technology is the application in transgenesis, since stem cells are easily genetically engineered and selected. After the process of differentiation, these gametes could be used to generate transgenic animals. 
Differentiation toward gametes represents the extraordinary advances in the developmental biology, biology of reproduction, stem cell biology. Further investigation of this amazing type of differentiation implicates with great biotechnological progress in regards of genetic amelioration of livestock and preservation of genetic fund of the animals in extinction. In humans, this research can contribute significantly for understanding of genetic and cellular mechanisms of infertility. However, the use of artificial gametes in assisted reproductive technologies is implicated with huge ethical problems, which should be well thought and discussed before this technique will become a reality in Reproductive Medicine (Testa \& Harris, 2004).

\section{References}

Adams I.R. \& McLaren A. (2002). Sexually dimorphic development of mouse primordial germ cells: switching from oogenesis to spermatogenesis. Development 129, pp. 1155-1164.

Aflatoonian, B., \& Moore, H. (2006). Germ cells from mouse and embryonic stem cells. Reproduction 132, pp. 1-10.

Aflatoonian, B.; Fazeli, A.; Ruban, L; Jones, M.; Andrews, P.W.; Moore, H.D.M. (2005). Human embryonic stem cells differentiate to primordial germ cells as determined by gene expression profiles and antibody markers. Human Reproduction 20 pp. i6.

Aflatoonian, B.; Ruban, L.; Jones, M.; Aflatoonian, R.; Fazeli, A.; Moore, H.D. (2009). In vitro post-meiotic germ cell development from human embryonic stem cells. Hum Reprod. Dec; 24 (12) pp. 3150-9.

Allegrucci, C.; Thurston, A.; Lucas, E. \& Young, L. (2005). Epigenetics and the germline. Reproduction 129, pp. 137-149.

Anderson, E. L.; Baltus, A. E.; Roepers-Gajadien, H. L.; Hassold, T.J.; de Rooij, D. G.; van Pelt, A.M.M. \& Page, D.C. (2008). Stra8 and its inducer, retinoic acid, regulate meiotic initiation in both spermatogenesis and oogenesis in mice. Proc. Natl Acad. Sci. USA 105, pp. 14976-14980.

Arnaud, P. (2010). Genomic imprinting in germ cells: imprints are under control. Reproduction 140(3), pp. 411-23.

Assou, S., Anahory, T., Pantesco, V., Le Carrour, T.; Pellestor, F.; Klein, B.; Reyftmann, L.; Dechaud, H.; De Vos, J.; Hamamah, S. (2006). The human cumulus-oocyte complex gene-expression profile. Human Reproduction 7, pp. 1705-1719.

Baillie, H.S.; Pacey, A.A. \& Moore, H.D.M. (2003). Environmental chemicals and the threat to male fertility in mammals: evidence and perspective. In Conservaion Biology 8. Reproductive Science and Integrated Conservation, pp 57-66.

Bassols , J.; Kádár, E.; Briz, M.; Pinart, E.; Sancho, S.; Garcia-Gil, N.; Badia, E.; Pruneda, A.; Bussalleu, E.; Yeste, M.; Casas, I.; Dacheux, J.L.; Bonet, S. (2005). Evaluation of boar sperm maturation after co-incubation with caput, corpus and cauda epididymal cultures. Evaluation of boar sperm maturation in vitro. Theriogenology, v.64 pp. 1995-2009.

Bowles, J. \& Koopman, P. (2007). Retinoic acid, meiosis and germ cell fate in mammals. Development 134, pp. 3401-3411.

Bowles, J., Knight, D., Smith, C., Wilhelm, D.; Richman, J.; Mamiya, S.; Yashiro, K.; Chawengsaksophak, K.; Wilson, M.J.; Rossant, J.; Hamada, H.; Koopman, P. (2006). Retinoid signaling determines germ cell fate in mice. Science 312, pp. 596-600. 
Chen, Y.; Jefferson, W.N.; Newbold, R.R.; Padilla-Banks, E.; Pepling, M.E. (2007). Estradiol, progesterone, and genistein inhibit oocyte nest breakdown and primordial follicle assembly in the neonatal mouse ovary in vitro and in vivo. Endocrinology. Aug; 148 (8) pp. 3580-90.

Clark, A.T. ; Bodnar, M.S. ; Fox, M., Rodriquez, R.T.; Abeyta, M.J.; Firpo, M.T. \&.Pera, R.A. (2004). Spontaneous differentiation of germ cells from human embryonic stem cells in vitro. Hum. Mol. Genet. 13, pp. 727-739.

Cornwall, G.A. (2009). New insights into epididymal biology and function. Human Reproduction Update, v.15, n.2 pp. 213-227.

Daley, G.Q. (2007). Gametes from embryonic stem cells: a cup half empty of half full? Science v. 316, pp. 409-410.

de Napoles, M.; Nesterova, T. \& Brockdorff, N. (2007). Early loss of Xist RNA expression and inactive $\mathrm{X}$ chromosome associated chromatin modification in developing primordial germ cells. PLoS ONE 2, e860.

Donovan, P.J. \& de Miguel M.P. (2003). Turning germ cells into stem cells. Current Opinion in Genetics \& Development 13, pp. 463-471.

Doyle, T.J.; Braun, K.W.; McLean, D.J.; Wright, R.W.; Griswold, M.D.; Kim, K.H. (2007). Potential functions of retinoic acid receptor A in Sertoli cells and germ cells during spermatogenesis. Ann N Y Acad Sci. Dec;1120 pp.114-30.

Evans, M.J. \& Kaufman, M.H. (1981). Establishment in culture of pluripotential cells from mouse embryos. Nature 292, pp. 154-156.

Fenderson, B.A., O'Brien, D.A., Millette, C.F., and Eddy, E.M. (1984). Stage-specific expression of three cell surface carbohydrate antigens during murine spermatogenesis detected with monoclonal antibodies. Dev. Biol. 103, pp. 117-128.

Fledel-Alon, A. ; Wilson, D.J.; Broman, K.; Wen, X.; Ober, C.; Coop, G.; Przeworski, M. (2009). Broad-scale recombination patterns underlying proper disjunction in humans. PLoS Genet. 5, pp. e1000658.

Geijsen, N.; Horoschak, M.; Kim, K., Gribnau, J. Eggan, K. \& Daley, G.Q. (2004). Derivation of embryonic germ cells and male gametes from embryonic stem cells. Nature 427, pp. 148-154.

Goldberg, A. D.; Allis, C.D. \& Bernstein, E. (2007). Epigenetics: a landscape takes shape. Cell 128, pp. 635638.

Handel, M.A. \& Schimenti, J.C. (2010). Genetics of mammalian meiosis: regulation, dynamics and impact on fertility. Nature Reviews Genetics 11, pp. 124-136.

Hassold, T.; Hall, H. \& Hunt, P. (2007). The origin of human aneuploidy: where we have been, where we are going. Hum. Mol. Genet. 16, pp. R203-R208.

Hsieh, M.; Zamah, A. M. \& Conti, M. (2009). Epidermal growth factor-like growth factors in the follicular fluid: role in oocyte development and maturation. Semin.Reprod. Med. 27, pp. 52-61.

Hua, J.\& Sidhu, K. (2008). Recent advances in the derivation of germ cells from the embryonic stem cells. Stem cells and Development, v.17, pp. 399-411.

Hübner, K.; Fuhrmann, G.; Christenson, L.K.; Kehler, J.; Reinbold, R.; De La Fuente, R.; Wood, J.; Strauss, J.F. III, Boiani, M. \& Scholer, H.R. (2003). Derivation of oocytes from mouse embryonic stem cells. Science 300, pp. 1251-1256. 
Kee, K.; Angeles, V.T.; Flores, M.; Nguyen, H.N. \& Pera, R.A.R. (2009). Human DAZL, DAZ and BOULE genes modulate primordial germ-cell and haploid gamete formation. Nature 462, pp. 222-227.

Kee, K.; Gonsalves, J.M.; Clark, A.T.; Pera, R.A. (2006). Bone morphogenetic proteins induce germ cell differentiation from human embryonic stem cells. Stem Cells Dev 15, pp. 831-837.

Kerkis, I.; Fonseca, S.A.S.; Serafim, R.C.; Lavagnolli, T.M.; Abdelmassih, S.; Abdelmassih, R.; Kerkis, I. (2007). In vitro differentiation of male mouse embryonic stem cells into both presumptive sperm cells and oocytes. Cloning Stem Cells 9, pp. 535-548.

Ko, K. \& Schöler, H.R. (2006). Embryonic stem cells as a potential source of gametes. Semin Reprod Med. i24, pp. 322.

Koerner, M.V.; Barlow, D.P. (2010). Genomic imprinting-an epigenetic gene-regulatory model. Curr Opin Genet Dev. Apr;20(2), pp. 164-70.

Koshimizu, U.; Watanabe, M. \& Nakatsuji, N. (1995). Retinoic acid is a potent growth activator of mouse primordial germ cells in vitro. Dev. Biol. 168, pp. 683-685.

Koubova, J.; Menke, D.B.; Zhou, Q.; Capel, B.; Griswold, M.D. Page, D.C. (2006). Retinoic acid regulates sex-specific timing of meiotic initiation in mice. Proc. Natl Acad. Sci. USA 103, pp. 2474-2479.

Kuijk, E.W.; Chuva de Sousa Lopes, S.M.; Geijsen, N.; Macklon, N.; Roelen, B.A. (2010). The different shades of mammalian pluripotent stem cells. Hum Reprod Update. Aug 12. [Epub ahead of print]

Lacham-Kaplan O, Chy H \& Trounson A 2006 Testicular cell conditioned medium supports differentiation of embryonic stem cells into ovarian structures containing oocytes. Stem Cells 24, pp. 266-273

Lacham-kaplan, O. \& Trounson, A.O. (1991). Fertilizing capacity of epididymal and testicular spermatozoa microinjected under the zona pellucida of the mouse oocyte. Mol Reprod. Dev. 29, pp. 85-93. apud TROUNSON, A.;

Lavagnolli, T.M.; Fonseca, S.A.; Serafim, R.C.; Pereira, V.S.; Santos, E.J.; Abdelmassih, S.; Kerkis, A.; Kerkis I. (2009). Presumptive germ cells derived from mouse pluripotent somatic cell hybrids. Differentiation. Sep-Oct; 78(2-3) pp.124-30.

Le Bouc, Y.; Rossignol, S.; Azzi, S.; Steunou, V.; Netchine, I.; Gicquel, C. (2010). Epigenetics, genomic imprinting and assisted reproductive technology. Ann Endocrinol (Paris). May;71(3), pp.237-8.

Lin, Y; Gill, M. E. ; Koubova, J. \& Page, D. C. (2008). Germ cell-intrinsic and -extrinsic factors govern meiotic initiation in mouse embryos. Science 322, pp. 1685-1687.

Lupski, J. R. \& Stankiewicz, P. (2005). Genomic disorders: molecular mechanisms for rearrangements and conveyed phenotypes. PLoS Genet, 1, pp. e49.

Marques-Mari, A.I.; Lacham-Kaplan, O.; Medrano, J.V.; Pellicer, A.; Simón, C. (2009). Differentiation of germ cells and gametes from stem cells. Hum Reprod Update. MayJun;15(3) pp. 379-90.

Martin, G.R. (1981). Isolation of a pluripotent cell line from early mouse embryos cultured in medium conditioned by teratocarcinoma stem cells. PNAS 78, pp. 7634-7638.

McLaren, A. (2003). Primordial germ cells in the mouse. Developmental Biology 262, pp. 1-15.

Miozzo, M. \& Simoni, G. (2002). The role of imprinted genes in fetal growth. Biology of the Neonate 81, pp. 217-228. 
Mittmann, J.; Kerkis, I.; Kawashima, C.; Sukoyan, M.; Santos, E.; Kerkis, A. (2002). Differentiation of mouse embryonic stem cells and their hybrids during embryoid body formation. Gen. Mol. Biol. 25 (1), pp. 103-111.

Monk, M. \& McLaren, A. (1981). X-chromosome activity in foetal germ cells of the mouse. $I$ Embryol. Exp. Morphol. 63, pp. 75-84.

Moore, H.; Aflatoonian, B. (2007). From stem cells to spermatozoa and back. Soc Reprod Fertil Suppl; 65, pp. 19-32.

Moore, H.D. (1990). Development of sperm-egg recognition processes in mammals. $J$ Reprod. Fertil. Suppl. v.42, pp.71-78.

Nagano, M.C. (2007). In vitro gamete derivation from pluripotent stem cells: progress and perspective. Biol Reprod. Apr; 76(4) pp. 546-51.

Nagy, Z.P.; Kerkis, I. \& Chang, C.C. (2008). Development of artificial gametes. Reproductive BioMedicine Online. 16(4), pp. 539-544.

Nayernia, K.; Nolte, J.; Michelmann, H.W.; Lee, J.H., Rathsack, K., Drusenheimer, N.; Dev, A.; Wulf, G.; Ehrmann, I.E.; Elliott, D.J.; Okpanyi, V.; Zechner, U.; Haaf, T.; Meinhardt, A.; Engel, W. (2006). In vitro-differentiated embryonic stem cells give rise to male gametes that can generate offspring mice. Dev. Cell 11, pp. 125-132.

Novak, I.; Lightfoot, D.A.; Wang, H.; Lee, H.J.; Adams, G.B.; Niikura, Y.; Tschudy, K.S.; Tilly, J.C.; Tortes, M.L.; Forkert, R.; Spirtzer, T.; Iacomini, J.; Scadden, D.T.; Tilly, J.L. (2006). Mouse Embryonic stem cells form follicle-like ovarian structures but do not progress through meiosis. Stem Cells 24, pp. 1931-1936.

Palmer, S.J. \& Burgoyne, P.S. (1991). The Mus musculus domesticus Tdy allele acts later than the Mus musculus Tdy allele: a basis for XY sex-reversal in C57BL/6-YPOS mice. Development. Oct;113(2) pp.709-14.

Park, T.S.; Galic, Z.; Conway, A.E.; Lindgren, A.; van Handel, B.J.; Magnusson, M.; Richter, L.; Teitell, M.A.; Mikkola, H.K.; Lowry, W.E. (2009). Derivation of primordial germ cells from human embryonic and induced pluripotent stem cells is significantly improved by coculture with human fetal gonadal cells. Stem Cells 27, pp. 783-795.

Qing, T.; Shi, Y.; Qin, H.; Ye, X.; Wei, W.; Liu, H.; Ding, M.; Deng, H. (2007). Induction of oocyte-like cells from mouse embryonic stem cells by co-culture with ovarian granulosa cells. Differentiation. Dec; 75 (10) pp. 902-11.

Reik, W. (2007). Stability and flexibility of epigenetic gene regulation in mammalian development. Nature 447, pp. 425-432.

Robaire, B.; Hinton, B.T.; Orgebin-Crist, M.C. (2006). The Epididymis, cap 22, pp. 1071-1148. In: Knobil and Neill's, Physiology of Reproduction, $3^{\text {th }}$ Ed, Elsevier Inc.

Salvador, L.M.; Silva, C.P.; Kostetskii, I.; Radice, G.L.; Strauss, J.F. (2008). The promoter of the oocyte-specific gene, Gdf9, is active in population of cultured mouse embryonic stem cells with an oocyte-like phenotype. Methods. Jun; 45 (2) pp. 172-81.

Sasaki, H. \& Matsui, Y. (2008). Epigenetic events in mammalian germ-cell development: reprogramming and beyond. Nature Reviews Genetics 9, pp. 129-140.

Schlecht, U.; Demougin, P.; Koch, R.; Hermida, L.; Wiederkehr, C.; Descombes, P.; Pineau, C.; Jégou, B.; Primig, M. (2004). Expression profiling of mammalian male meiosis and gametogenesis identifies novel candidate genes for roles in the regulation of fertility. Mol. Biol. Cell. 15, pp. 1031-1043. 
Shima, J. E.; McLean, D. J.; McCarrey, J. R. \& Griswold, M. D. (2004).The murine testicular transcriptome: characterizing gene expression in the testis during the progression of spermatogenesis. Biol. Reprod. 71, pp. 319-330.

Sugimoto, M. \& Abe, K. (2007). X chromosome reactivation initiates in nascent primordial germ cells in mice. PLoS Genet. 3, pp. 1309-1317.

Takahashi, K. \& Yamanaka, S. (2006) Induction of pluripotent stem cells from mouse embryonic and adult fibroblast cultures by defined factors. Cell 126 (4), pp. 663-676.

Takahashi, K.; Tanabe, K.; Ohnuki, M.; Narita, M.; Ichisaka, T.; Tomoda, K.; Yamanaka, S. (2007). Induction of pluripotent stem cells from adult human fibroblasts by defined factors. Cell 131, pp. 861-872.

Tam, P.P.; Zhou, S.X. \& Tan, S.S. (1994). X- chromosome activity of the mouse primordial germ cells revealed by the expression of an X-linked lac $Z$ transgene. Development 120, pp. 2925-2932.

Tchieu, J.; Kuoy, E.; Chin, M.H.; Trinh, H.; Patterson, M.; Sherman, S.P.; Aimiuwu, O.; Lindgren, A.; Hakimian, S.; Zack, J.A.; Clark, A.T.; Pyle, A.D.; Lowry, W.E.; Plath, K. (2010). Female human iPSCs retain an inactive X chromosome. Cell Stem Cell, Sep 3; 7 (3) pp.329-42.

Testa, G. \& Harris, J. (2004). Ethical Aspects of ES Cell-Derived Gametes. Science 305, pp. 1719.

Thomson, J.A.; Itskovitz-Eldor, J; Shapiro, S.S; Waknitz, M.A.; Swiergiel, J.J.; Marshall, V.S. \& Jones, J.M. (1998). Embryonic stem cell lines derived from human blastocysts. Science 282, pp. 1145-1147.

Tilgner, K.; Atkinson, S.P.; Golebiewska, A.; Stojkovic, M.; Lako, M.; Armstrong, L. (2008). Isolation of primordial germ cells from differentiating human embryonic stem cells. Stem Cells 26, pp. 3075-3085.

Toyooka, Y.; Tsunekawa, N.; Akasu, R.; \& Noce, T. (2003). Embryonic stem cells can form germ cells in vitro. Proc. Natl. Acad. Sci. USA 100, pp. 11457-11462.

Vasilkova, A.A.; Kizilova, H.A.; Puzakov, M.V.; Shilov, A.G.; Zhelezova, A.I.; Golubitsa, A.N.; Battulin N.R.; Vedernikov, V.E.; Menzorov, A.G.; Matveeva, N.M.; Serov, O.L. (2007). Dominant manifestation of pluripotency in embryonic stem cell hybrids with various numbers of somatic chromosomes. Mol Reprod Dev. Aug; 74 (8) pp. 941-51.

Wei, W.; Qing, T.; Ye, X.; Liu, H.; Zhang, D.; Yang, W.; Deng, H. (2008). Primordial Germ Cell Specification from Embryonic Stem Cells. PLoS ONE 3(12) pp. e4013.

West, F.D.; Machacek, D.W.; Boyd, N.L.; Pandiyan, K.; Robbins, K.R.; Stice, S.L. (2008). Enrichment and differentiation of human germ-like cells mediated by feeder cells and basic fibroblast growth factor signaling. Stem Cells 26, pp. 2768-2776.

West, F.D.; Roche-Rios, M.I.; Abraham, S.; Rao, R.R.; Natrajan, M.S.; Bacanamwo, M.; Stice, S.L. (2010). KIT ligand and bone morphogenetic protein signaling enhances human embryonic stem cell to germ-like cell differentiation. Hum Reprod. Jan; 25 (1) pp. 168-78.

Western, P.S.; van den Bergen, J.A.; Miles, D.C. \& Sinclair, A.H. (2010). Male fetal germ cell differentiation involves complex repression of the regulatory network controlling pluripotency. FASEB I 24, pp. 3026-3035.

Wong, E. W. P. \& Cheng, C. Y. (2009). Polarity proteins and cell-cell interactions in the testis International Review of Cell and Molecular Biology, V. 278, pp. 309-353. 
Yabuta, Y.; Kurimoto, K.; Ohinata, Y.; Seki, Y.; Saitou, M. (2006) Gene expression dynamics during germline specification in mice identified by quantitative single cell gene expression profiling. Biol Reprod 75, pp.705-716.

Yu, Z.; Ji, P.; Cao, J.; Zhu, S.; Li, Y.; Zheng, L.; Chen, X.; Feng, L. (2009). Dazl Promotes Germ Cell Differentiation from Embryonic Stem Cells. eburnal of Molecular Cell Biology 1, pp. 93-103.

Zhou, G.B.; Meng, Q.G.; Li, N. (2010) In vitro Derivation of Germ Cells from Embryonic Stem Cells in Mammals. Molecular Reproduction \& Development 77, pp. 586-594. 


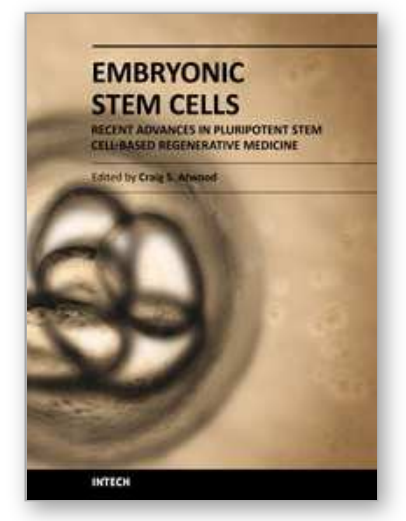

\section{Embryonic Stem Cells - Recent Advances in Pluripotent Stem Cell- Based Regenerative Medicine \\ Edited by Prof. Craig Atwood}

ISBN 978-953-307-198-5

Hard cover, 410 pages

Publisher InTech

Published online 26, April, 2011

Published in print edition April, 2011

Pluripotent stem cells have the potential to revolutionise medicine, providing treatment options for a wide range of diseases and conditions that currently lack therapies or cures. This book describes recent advances in the generation of tissue specific cell types for regenerative applications, as well as the obstacles that need to be overcome in order to recognize the potential of these cells.

\section{How to reference}

In order to correctly reference this scholarly work, feel free to copy and paste the following:

Irina Kerkis, Camilla M. Mendes, Simone A. S. da Fonseca, Nelson F. Lizier, Rui C. Serafim and Alexandre Kerkis (2011). Actual Achievements on Germ Cells and Gametes Derived from Pluripotent Stem Cells, Embryonic Stem Cells - Recent Advances in Pluripotent Stem Cell-Based Regenerative Medicine, Prof. Craig Atwood (Ed.), ISBN: 978-953-307-198-5, InTech, Available from: http://www.intechopen.com/books/embryonicstem-cells-recent-advances-in-pluripotent-stem-cell-based-regenerative-medicine/actual-achievements-ongerm-cells-and-gametes-derived-from-pluripotent-stem-cells

\section{INTECH}

open science | open minds

\section{InTech Europe}

University Campus STeP Ri

Slavka Krautzeka 83/A

51000 Rijeka, Croatia

Phone: +385 (51) 770447

Fax: +385 (51) 686166

www.intechopen.com

\section{InTech China}

Unit 405, Office Block, Hotel Equatorial Shanghai

No.65, Yan An Road (West), Shanghai, 200040, China

中国上海市延安西路65号上海国际贵都大饭店办公楼405单元

Phone: +86-21-62489820

Fax: $+86-21-62489821$ 
(C) 2011 The Author(s). Licensee IntechOpen. This chapter is distributed under the terms of the Creative Commons Attribution-NonCommercialShareAlike-3.0 License, which permits use, distribution and reproduction for non-commercial purposes, provided the original is properly cited and derivative works building on this content are distributed under the same license. 